\title{
ラットにおける強化系列の習得と消去に及ぼす 項目配列の効果
}

\section{金沢大学 谷内通}

Effects of item-arrangement on serial pattern learning and extinction in rats

Tohru Taniuchi (Graduate School of Socio-Environmental Studies, Kanazawa University, Kakuma-machi, Kanazawa 920-11)

Two experiments using rats as subjects examined effects of item-arrangement on acquisition and extinction in serial learning. In Experiment 1, Group A received series of $16^{-0} 0^{-16}$ and $1^{-0} 0^{-1}$ food pellets in a runway, while Group D received 1-0-16 and 16-0-1 series. Both groups manifested a remote anticipation of the third item on Run 2 , and current anticipation of the third item on Run 3. In extinction phase, resistance was greater in Group D than Group A. These results indicate that the first item signaled not only the second item, but also the third item. In Experiment 2, two of the four groups were trained with either of the following monotonic series: $0-16-0-8-0-4-$ 0-2-0-1 (Group M16) or 0-1-0-2-0-4-0-8-0-16 (Group M1), while the other two groups were given one of the following nonmonotonic series: $0-16-0-2-0-4-0-8-0-1$ (Group NM16) or 0-1-0-8-0-4-0-2-0-16 (Group NM1). In extinction phase, Group M16 showed the least resistance. These results are discussed mainly on the basis of remote association view and structural complexity theory of serial learning.

Key words: rats, serial learning, associative learning, rule learning, runway.

直線走路を用いたラットの系列学習研究では, 継起 する走行に対して与える報酬量 (45 mg の慨ペレッ トの数）を項目として系列を構成する（e.g., 14-7-3$1-0$ : 数字はペレット数)。このとき, 大報酬よりも小 報酬，特に無報酬に対して遅く走行することが学習の 指標とされる。しかし，どのような系列も等しく学習 されるのではなく, 項目配列は各項目に対する予期の 正確さに大きく影響する (e.g., Hulse \& Dorsky, 1977)。このように項目配列が項目予期に影響する機 制については，法則符号化仮説（e.g., Hulse, 1978; Hulse \& Dorsky, 1977) と記憶弁別理論 (e.g., Capaldi \& Molina, 1979) という二つの仮説が提起さ れている.

Hulse \& Dorsky（1977）は，項目配列が 14-7-3-1-0 のいわゆる強単調系列と 14-5-5-1-0 の弱単調系列, および 14-1-3-7-0 の非単調系列を比較した結果，ラ ットは強単調系列の 0 ペレットに対して最も遅く走行 する，すなわち0ペレットを正確に予期することを見 いだした。彼らは，この結果を基に，ラットは法則構 造を符号化および表象することによって系列を学習す るため, 単純な法則構造をもつ系列ほど速やかに学習 されるとする法則符号化仮説を提起した。法則構造と は，隣接する項目間の増減関係を時系列に沿って表し た際の規則性である。例えば, 14-7-3-1-0 系列内の 第 $i$ 番目の項目と第 $i+1$ 番目の項目間の関係は $\mathrm{I}[i]$
$>\mathrm{I}[i+1]$ ( $\mathrm{I}:$ 項目， $i:$ 系列位置 $)$ という単一の法則 によって記述できる。これに対し, 弱単調系列や非単 調系列の法則構造を記述するためには複数の法則が必 要になる。このため, 法則構造の符号化が最も容易で ある強単調系列において，0ペレットが最も容易に予 期されると説明される。

これに対し, Capaldi \& Molina (1979) は 15-10-50 強単調系列よりも 14-14-2-0 弱単調系列において, 0 ペレットが正確に予期されることを見いだした。彼 らは，この結果に基づき，項目間連合の形成によって 系列学習を説明する記憶弁別理論を提起した。記憶弁 別理論によると, ある走行で生じた報酬量に関する記 憶表象は次の走行で生じる報酬量を信号する弁別手が かり，すなわちシグナルとして機能する，また，項目 予期の正確さは，その項目のシグナルに対して生じる 他のシグナルからの刺激般化に依存する。例えば， 15-10-5-0 強単調系列では, 15 ペレットについての記 憶表象である $\mathrm{S}^{15}$ というシグナルが 10 ペレットを信 号する $\left(\mathrm{S}^{15} \rightarrow 10\right)$ ほかに, $\mathrm{S}^{10}\left(\mathrm{~S}^{10} \rightarrow 5\right)$, および $\mathrm{S}^{5}\left(\mathrm{~S}^{5}\right.$ $\rightarrow 0)$ といったシグナルが生起する。14-14-2-0 弱単 調系列では $\mathrm{S}^{14} \rightarrow 14, \mathrm{~S}^{14} \rightarrow 2$, および $\mathrm{S}^{2} \rightarrow 0$ といった 項目間連合が形成される。強単調系列の $S^{5}$ と弱単調 系列の $S^{2}$ は 0 ペレットのシグナルであるが，これら に対しては他のシグナルから報酬信号強度の刺激般化 が生じる。この刺激般化の大きさはシグナル間の類似 
性によって決定される. 強単調系列の $S^{5}$ と $S^{15} や S^{10}$ との間の類似性は, 弱単調系列の $\mathrm{S}^{2}$ と $\mathrm{S}^{14}$ との間の 類似性よりも高い。このため, 強単調系列では大報酬 を信号する $\mathrm{S}^{15}$ や $\mathrm{S}^{10}$ から $\mathrm{S}^{5}$ へ刺激般化が生じる傾向 は強いが, 弱単調系列の $S^{2}$ に対して生じる $S^{14}\left(S^{14} \rightarrow\right.$ 14）からの般化傾向は比較的弱いと期待される。 その 結果，0ペレットに対する走行は，15-10-5-0 系列よ りも14-14-2-0系列において遅くなると説明される。

法則符号化仮説や記憶弁別理論は系列の習得に関す る仮説であった。水原（1993）はこれらの仮説を消去 過程に適用し，項目配列が消去抵抗に影響することを 見いだした。彼は，14-7-3-1-0 単調系列よりも14-13-7-0 非単調系列習得後の消去抵抗が高い傾向にある こと（実験 1)，報酬項目間に0ペレットを挿入した 14-0-7-0-3-0-1-0 単一交替単調系列と 14-0-1-0-3-07-0 単一交替非単調系列では, 非単調系列習得後の消 去抵抗が高いこと（実験 2）を報告している.

水原（1993）は，14-0-7-0-3-0-1-0 系列の習得時 に観察された報酬量予期は，報酬項目同士が隣接して いないので，項目間連合の形成からは説明不可能であ るとした。また，単一交替系列間で観察された消去抵 抗の差異についても, 各シグナルが獲得すると期待さ れる報酬信号強度が系列間で等しくなるので，項目間 連合の形成からは説明不可能であるとされた。代わり に，水原（1993）は，ラットは法則学習により系列を 習得し, 系列の法則構造が単純であるほど強化刺激の 変化に対する構えを形成しやすいため, 習得から消去 への移行の弁別が容易になり，消去抵抗が低くなると する仮説を提起した。なお, 本研究では, この水原 （1993）の仮説を法則弁別仮説と呼ぶ.

水原 (1993) の理解は, 項目間連合は隣接した項目 の間にのみ形成されるという前提に基づいたものであ る.しかし，この前提に反して，項目間連合は隣接す る項目間だけでなく，遠隔した項目間にも形成される ことが報告されている (Capaldi \& Miller, 1988; Capaldi, Nawrocki, \& Verry, 1983; Capaldi \& Verry, 1981)。例えば，同じラットに X-0-Y 系列と Z-0-0 系列（X，Y，および $\mathrm{Z}$ は質的に異なる報酬を表す）
て第 3 項目を信号する傾向を獲得する (Capaldi \& Verry, 1981）ために，第 2 走行において第 3 項目の遠 隔予期が生じたことを示している。これらの結果は, 第 1 項目が，隣接する第 2 項目のシグナルだけでな く，遠隔した第 3 項目のシグナルの一部にもなりうる ことを実証するものである。このような遠隔した項目 間の連合は遠隔連合（remote association）と呼ばれ る。なお，本研究では，遠隔連合と区別するために， 隣接する項目間の連合を隣接連合と呼ぶ。

水原（1993）の研究で得られた習得時の走行パタン や消去抵抗に関する結果は，法則弁別仮説よりも，隣 接連合に加えて遠隔連合を仮定した記憶弁別理論によ って統一的に説明されるように思われる。例えば，水 原（1993，実験 2) では，14-0-1-0-3-0-7-0 単一交替 非単調系列における 0 ペレットに対する走行は, 先行 する報酬項目が大報酬の場合に遅く，小報酬の場合に 速い。これとは逆に，14-0-7-0-3-0-1-0 単一交替単 調系列に扔ける 0 ペレットに対する走行は，先行する 項目が大報酬の場合に速く，小報酬の場合に遅くなつ ている。法則符号化仮説では単一交替系列における 0 ペレット予期を “交替” 法則の学習によって説明する ので, 単一交替単調系列と単一交替非単調系列の間で 0 ペレットは等しく予期されると予測する。このた め, 法則符号化仮説は，0ペレット間の走行速度の分 化の仕方が両系列において異なるという結果について は説明できない。

これに対し，遠隔連合を仮定した記憶弁別理論は， 0 ペレット間の走行速度の分化の仕方が交替系列間で 異なることを次のように説明する。まず，14-0-7-03-0-1-0 系列と 14-0-1-0-3-0-7-0 系列の 0ペレット は， $\mathrm{S}^{14}, \mathrm{~S}^{7}, \mathrm{~S}^{3}$ ，および $\mathrm{S}^{1}$ をシグナルとした隣接連合 に基づいて信号される $\left(\mathrm{S}^{14} \rightarrow 0, \mathrm{~S}^{7} \rightarrow 0, \mathrm{~S}^{3} \rightarrow 0, \mathrm{~S}^{1} \rightarrow\right.$ 0)。また，両系列における $S^{0}$ は，隣接連合を通じて， 報酬項目，を信号する $\left(\mathrm{S}^{0} \rightarrow 7, \mathrm{~S}^{0} \rightarrow 3, \mathrm{~S}^{0} \rightarrow 1\right)$ ，このた め, $\mathrm{S}^{0}$ から $\mathrm{S}^{14}, \mathrm{~S}^{7}, \mathrm{~S}^{3}$ ，および $\mathrm{S}^{1}$ へは報酬信号傾向が 般化することになるが，この傾向は $\mathrm{S}^{0}$ との類似性が 最も高い $S^{1}$ において最も強く, $S^{0}$ との類似性が最も 低い $\mathrm{S}^{14}$ に扔いて最も弱いと考光られる.よって, 両 系列における 0 ペレットに対する走行は，先行する項 目の報酬量が小さい活ど速くなる傾向があると考元ら れる。しかし，0ペレットに後続する報酬項目はさま ざまであるので, $\mathrm{S}^{0}$ は後続の報酬項目の具体的な報 酬量を弁別するためのシグナルとしては有効ではな い.このため，0ペレットに後続する報酬項目は直前 の0ペレットの記憶とその前の報酬項目の記憶を結合 した複合記憶をシグナルとして信号されると考えられ る。このとき, $\mathrm{S}^{14}, \mathrm{~S}^{7}, \mathrm{~S}^{3}$ ，および $\mathrm{S}^{1}$ 等の単一記憶は，

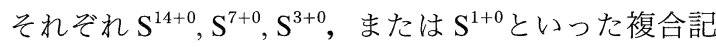
憶からの刺激般化を通じて報酬信号傾向を獲得するの で，大報酬を信号する複合記憶から刺激般化を受ける 
単一記憶に続く 0 ペレットに対する走行ほど速くなる と期待される。

ここで，14-0-7-0-3-0-1-0 系列における， $\mathrm{S}^{14}, \mathrm{~S}^{7}$, $\mathrm{S}^{3}$, および $\mathrm{S}^{1}$ では, 隣接連合によって報酬項目を信 号する $\mathrm{S}^{0}$ と類似性の低いシグナルほど, 複合記憶か らの刺激般化を通じて大報酬を信号している。例え ば，14ペレットに後続する 0 ペレットに対する走行 では，0ペレットを信号する $\mathrm{S}^{14}\left(\mathrm{~S}^{14} \rightarrow 0\right)$ が $\mathrm{S}^{0}$ から刺 激般化を受ける傾向は弱いが， $S^{14+0}\left(S^{14+0} \rightarrow 7\right)$ とい う比較的大報酬を信号する複合記憶から刺激般化を受 けるために，比較的速い走行が生じる傾向がある。ま た， 3 ペレットに後続する 0 ペレットに対する走行で は, $\mathrm{S}^{3}\left(\mathrm{~S}^{3} \rightarrow 0\right)$ が $\mathrm{S}^{0}$ から刺激般化を受ける傾向は強 いが， $S^{3+0}\left(S^{3+0} \rightarrow 1\right)$ という小報酬を信号する複合記 憶から刺激般化を受けるために, 比較的遅い走行が生 じる傾向があると考えられる。これに対し，14-1-37-0 系列では走行速度の分化が示されない (e. g., 水 原，1993，実験 1）ことから，この系列の報酬項目間 に 0 ペレットを挿入した $14-0-1-0-3-0-7-0$ 系列にお いてもさまざまな報酬項目を信号する複合記憶間で刺 激般化が生じるために，0ペレットに対する走行に及 ぼす後続項目の報酬量の効果は比較的小さいと考えら れる。その結果，0ペレットに対する走行は，主に， 先行する報酬項目の記憶と $\mathrm{S}^{0}$ の類似性によって規定 され，報酬項目を信号する 0 ペレットとの類似性の高 い3ペレットや1ペレットに後続する 0 ペレットに対 して速い走行が生じる傾向があると説明される。

遠隔連合を仮定すると，水原（1993）の消去に関す る結果もまた項目間連合の枠組み内で説明可能である ように思われる。水原（1993）も認めているように， 14-7-3-1-0 単調系列よりも 14-1-3-7-0 非単調系列の 習得後の消去抵抗が高くなることは, 刺激残効理論の 刺激特殊性に関する仮説（Capaldi, 1967） から説明可 能である。すなわち，消去段階で生じる $\mathrm{S}^{0}$ と類似す る. $S^{1}$ は, 習得時に 14-7-3-1-0 単調系列では 0 ペレッ トを信号し，14-1-3-7-0 非単調系列では 3ペレット を信号していた，また， $\mathrm{S}^{1}$ に次いで $\mathrm{S}^{0}$ と類似する $\mathrm{S}^{3}$ は単調系列では 1 ペレットを信号し, 非単調系列では 7 ペレットを信号していた。このように，消去段階で 生じる $\mathrm{S}^{0}$ と類似する $\mathrm{S}^{1} や \mathrm{~S}^{3}$ が獲得する報酬信号強 度が，単調系列よりも非単調系列において大きいため に, 前者よりも後者の系列の習得後の消去抵抗が高く なると説明される。遠隔連合を仮定すると交替系列に も同じ原理が適用できる、14-0-7-0-3-0-1-0 単調系 列と 14-0-1-0-3-0-7-0 非単調系列では，隣接連合を 通じて各シグナルが獲得する報酬信号強度は等しいと 考えられる。しかし，隣接連合に加えて遠隔連合を仮 定すると, $\mathrm{S}^{1+0}$ は, 単調系列では信号の対象となる項 目をもたないが，非単調系列では 3 ペレットを信号す る。また, $\mathrm{S}^{3+0}$ は, 単調系列では 1 ペレット, 非単調
系列では 7 ペレットを信号する. 従って, 消去時に生 じる $\mathrm{S}^{0}$ と類似した $\mathrm{S}^{1} や \mathrm{~S}^{3}$ が複合記憶からの刺激般 化を通じて獲得する報酬信号強度は，単調系列よりも 非単調系列において大きくなると期待される。その結 果, 報酬項目間に0ペレット項目を挿入した場合に も，単調系列よりも非単調系列の消去抵抗が高くなる と説明される。

このように，水原（1993）の法則弁別仮説の根拠と なった交替系列の習得および消去の結果については, 隣接連合に加えて遠隔連合を仮定することにより, 項 目間連合の枠組み内で説明可能であると思われる。そ こで本研究においては，ラットの強化系列学習におけ る遠隔連合の形成と消去への関与を検討する（実験 1) とともに，単一交替系列の習得後の消去について 遠隔連合を仮定した記憶弁別理論と法則弁別仮説を比 較する（実験 2）ことを企図した。

\section{実 験 1}

水原（1993）の単一交替系列における0ペレットに 対する走行パタンを遠隔連合によって説明するために は，0ペレットに対する走行が，これに先行する報酬 項目と後続する報酬項目のそれぞれの報酬量に影響さ れることを明らかにする必要がある。このうち, 後続 する報酬項目の報酬量が大きいほど 0 ペレットに対す る走行が速くなることはすでに実証されている（e.g., Capaldi \& Miller, 1988). しかし, 先行する報酬項目 の報酬量が 0 ペレットに対する走行に与える効果につ いては, 単一交替系列の場合のように，0ペレットに 常に報酬項目が先行・後続するような事態においては 検討されていない. また, 遠隔した項目間の信号関係 が消去抵抗に与える効果についても検討されていな い. そこで, 実験 1 では，16-0-16と 1-0-1 という 2 系列を与える A (agreement) 群と 1-0-16 と 16-0-1 という 2 系列を与える D (disagreement) 群の習得と 消去を吟味することによって，これらの R[1]-N[2]-R [3] 系列（R：報酬項目， $\mathrm{N}$ ：無報酬項目）では，(1) 0ペレットに対する走行は, R[3]を信号する $\mathrm{S}^{\mathrm{N}[2]}$ $\left(\mathrm{S}^{\mathrm{N}[2]} \rightarrow \mathrm{R}[3]\right)$ から $\mathrm{N}[2]$ を信号する $\mathrm{S}^{\mathrm{R}[1]}\left(\mathrm{S}^{\mathrm{R}[1]} \rightarrow\right.$ $\mathrm{N}[2]$ ）に対して刺激般化が生じるために，0ペレット に先行する項目が小報酬であるほど速くなるという仮 説と, (2)遠隔した項目間で, 小報酬が小報酬を信号 する場合よりも小報酬が大報酬を信号する場合に消去 抵抗が高くなるという仮説とを検証することとした。

まず，隣接連合だけを仮定した場合には，両群にお いて形成される項目間連合は等しいと期待される $\left(\mathrm{S}^{16} \rightarrow 0, \mathrm{~S}^{1} \rightarrow 0, \mathrm{~S}^{0} \rightarrow 16, \mathrm{~S}^{0} \rightarrow 1\right) . \mathrm{S}^{0}$ からの般化傾向は $\mathrm{S}^{16}$ よりも $\mathrm{S}^{1}$ において大きい. 従って, 第 2 項目の 0 ペレットに対する走行は, 第 1 項目が 16 ペレットよ りも 1 ペレットの場合に速くなるが，この傾向は群間 で等しいと予測される（1-0-1=1-0-16>16-0-16= 
16-0-1).また，第 3 項目の 16 ペレットと 1 ペレット のシグナルはともに $\mathrm{S}^{0}$ であるので，第 3 走行におけ る走行速度の分化は両群に扔いて認められないと予測 される.消去については, 各シグナルが獲得する報酬 信号強度は両群間で等しいと期待されるため, 両群の 消去抵抗に差が認められるとは予測されない.

これに対し，隣接連合と遠隔連合の両者を仮定する と次のように予測される。 まず，上記のように， $\mathrm{S}^{16}$ $\rightarrow 0$ よりも $\mathrm{S}^{1} \rightarrow 0$ の方が $\mathrm{S}^{0} \rightarrow 16$ や $\mathrm{S}^{0} \rightarrow 1$ から刺激般 化を受ける傾向が大きいと期待されるので，0ペレッ 卜に対する走行は，第 1 項目が 16 ペレットの系列よ りも1 ペレットの系列において速くなる傾向があると 予測される。 また，0ペレットに対する走行では，第 3 項目の遠隔予期が生じるために第 3 項目が 1 ペレッ トの系列よりも16ペレットの系列において速くなる 傾向があると予測される.さらに，これらの予測を組 み合わせると， 0 ペレットに対する走行は，これに走 行する報酬量が最小で, 後続する報酬量が最大の 1 0-16系列において最も速くなり, 先行する報酬量が 最大で, 後続する報酬量が最小の 16-0-1 系列におい て最も遅くなると予測される。すなわち，0ペレット に対する走行速度の系列間の分化は, $\mathrm{A}$ 群よりも $\mathrm{D}$ 群に扔いて大きくなると予測される. 消去について は, 上述のように, 隣接連合によって各シグナルが獲 得する報酬信号強度は群間で等しいと期待される。し かし, 消去時に生じる $S^{0}$ と類似する $S^{1}$ へ刺激般化を 及ぼす複合記憶 $\mathrm{S}^{1+0}$ は，A 群では 1 ペレットという 小報酬を信号するが，D群では 16 ペレットという大 報酬を信号する。従って, 消去抵抗は $\mathrm{A}$ 群よりも $\mathrm{D}$ 群において高くなると予測される。

\section{方 法}

被験体 日本チャールズ・リバー社から購入した実 験経験のない Sprague Dawley 系の雄ラット12 匹を 用いた。被験体は，実験開始時に約 75 日齢であった。

装置 全長 $152 \mathrm{~cm}$, 幅 $10 \mathrm{~cm}$, 高さ $11 \mathrm{~cm}$ の廊下 式直線走路を用いた。走路は $30 \mathrm{~cm}$ の出発箱, $92 \mathrm{~cm}$ の走路, $30 \mathrm{~cm}$ の目標箱からなり, 出発箱と目標箱は ギロチンドアによって走路部分と仕切られていた。 目 標箱の末端には, 直径 $5 \mathrm{~cm}$ の餌血を設置した. 餌血 の手前 $17 \mathrm{~cm}$ のところに光電管を設置し, 出発箱の ギロチンドアを引き上げてから, ラットが光電をさえ ぎるまでの時間を $1 / 100$ 秒単位で測定した。報酬には $45 \mathrm{mg}$ の䬺ペレットを用いた。

手続き 本訓練に先だち 10 日間の予備訓練を行っ た.この期間に食餌制限によってラットの体重を自由 捸食時の $80 \pm 2 \%$ に減量し, この体重を実験が終了す るまで維持した。1ー7日目までは毎日 1 分間のハン ドリングを与えた。 8 日目と 9 日目には装置内の自由 探索を個別に 10 分間与えた。このとき, 目標箱の床
に置いた 10 粒の餌ペレットを食べさせた.10日目に はギロチンドアを閉めた目標箱内で餌血から 10 粒の 餌ペレットを食べさせた。

予備訓練終了の翌日から 28 日間の習得訓練を行っ た.ラットを無作為に 2 群に振り分けた $(n=6)$. A 群には 1-0-1 系列 ( $\mathrm{X}$ 系列) と 16-0-16 系列（Y 系 列)，D群には 16-0-1 (X 系列) 系列と 1-0-16 系列 （Y 系列）を 1 日に 2 回ずつ与えた. 各群の半数のラ ットには, 奇数日にXYYX, 偶数日に YXXY の順 で系列を提示し，残りの半数のラットには訓練日への 系列提示順序の割付けを逆にした。両群ともに走行間 間隔は 15-20 秒間，系列間間隔は 10-20 分間であっ た。

ラットを出発箱に入れ, 約 3 秒後にギロチンドアを 引き上げた。ラットが目標箱に達すると目標箱側のド アを降ろした。報酬項目の場合，ラットが慨ペレット を食べつくすと拘留用ケージに移し，走行間間隔の経 過後に次の走行を開始した。0ペレットの場合は目標 箱に 20 秒間留めた後に取り出した.ラットが 30 秒以 内に目標箱に達しない場合は，実験者が目標箱に入れ た.この場合の走行時間は 30 秒とした. 系列の最後 の走行が終了するとラットを待機用ケージに移し, 系 列間間隔の経過後に次の系列の提示を開始した.

習得訓練終了の翌日から 4 日間の消去訓練を行つ た。消去訓練ではすべてのラットに $0-0-0$ 系列を 1 日 に 4 回与えた。その他の手続きは習得訓練と同じであ った.

\section{結 果}

Figure 1 は両群の各項目に対する走行速度を 2 日ブ ロックで示している. 群 $(2) \times$ 系列 $(2) \times$ 走行 (3) $\times$ 日 ブロック(14)の分散分析を施した結果, 群 $\times$ 系列 $\times$ 走 行×日ブロックの交互作用が有意であった（ $F[26$, $260]=1.64, p<.05)$. 走行ごとに群×系列 $\times$ 日ブロッ クの単純交互作用を吟味したところ，第 2 走行におい てのみ有意であった $(F[13,390]=2.90, p<.01)$. 第 2 走行の日ブロックごとに群 $\times$ 系列の単純・単純交互作 用を吟味したところ第 10 ，第 12 ，および第 14 ブロッ クに扔いて有意であった $\left(F_{\mathrm{S}}[1,420]=4.02,7.78\right.$, $13.57, p<.05$ : 第 10 ブロック, $p \mathrm{~s}<.01$ : 第 $12 \cdot 14$ ブ ロック)。これらの交互作用について群扔よび系列の 単純・単純・単純主効果を吟味したところ，いずれの ブロックについても各系列における群の主効果は有意 ではなかった。しかし，各群における系列の主効果に ついては，D群ではこの 3 ブロックすべてにおいて 系列の主効果が有意である $(F \mathrm{~s}[1,420]=49.12,36.51$, $50.36, p \mathrm{~s}<.01 ）$ のに対し，A群における系列の主効 果は第 10 ブロック $(F[1,420]=17.43, p<.01)$ およ び第 12 ブロック $(F[1,420]=4.40, p<.05)$ では有意 であるが，第 14 ブロック $(F[1,420]=3.56)$ では有 
意ではなかった。これらの結果は, 習得訓練の最終段 階における0ペレットに対する走行の系列間の分化 が，A群よりもD群において大きかったことを示し ている。また，第 3 走行については系列 $\times$ 日ブロック の単純交互作用が有意であった $(F[1,390]=3.12, p<$ .01)。各日ブロックに扔ける系列の単純・単純主効果 を吟味したところ，第 $9,10,11,12,13$ ，および 14 ブ ロックに扔いて 16 ペレットよりも 1 ペレットに対す る走行が有意に遅かった $(F \mathrm{~s}[1,400]=8.99,7.99,6.27$, $12.65,11.91,18.36, p \mathrm{~s}<.01$, 第 10 ブロックについての み $p<.05)$.

Figure 2 は消去訓練における両群の遂行を示してい る. 群(2) X項目 (3) $\times$ 日(4)の分散分析を施したとこ ろ, 群 $(F[1,10]=6.52, p<.05)$, 項目 $(F[2,20]=$ $11.56, p<.01)$, 日 $(F[3,30]=18.18, p<.01)$ の主効 果, 抢よび項目 $\times$ 日の交互作用 $(F[6,60]=2.90, p<$ .05）が有意であった。群の主効果が有意であり, 消 去抵抗は $\mathrm{A}$ 群よりも D 群において高いことが示され た.

\section{考 察}

習得段階にお打第 2 走行の走行速度は, 第 3 項目 が 1ペレットである 1-0-1 系列や 16-0-1 系列よりも， 16ペレットである 16-0-16 系列や 1-0-16系列におい て速いことが示された。 また, 第 3 走行において, 両 群ともに16ペレットよりも1 ペレットに対して遅く 走行した.これらの結果は, 第 2 走行における第 3 項 目の遠隔予期や第 3 走行に打ける第 3 項目の当該予期
が生じることを示した Capaldi \& Miller（1988）の結 果を再確認するものである。 また，第 2 走行の 0 ペレ ットに対する走行速度の系列間の分化は $\mathrm{A}$ 群よりも $\mathrm{D}$ 群に扔いて大きいことが示された。この結果は，0 ペレットに対する走行が，これに後続する項目の報酬 量（Capaldi \& Miller, 1988）だけでなく，先行する項 目の報酬量にも規定されるとする本研究の仮説を支持

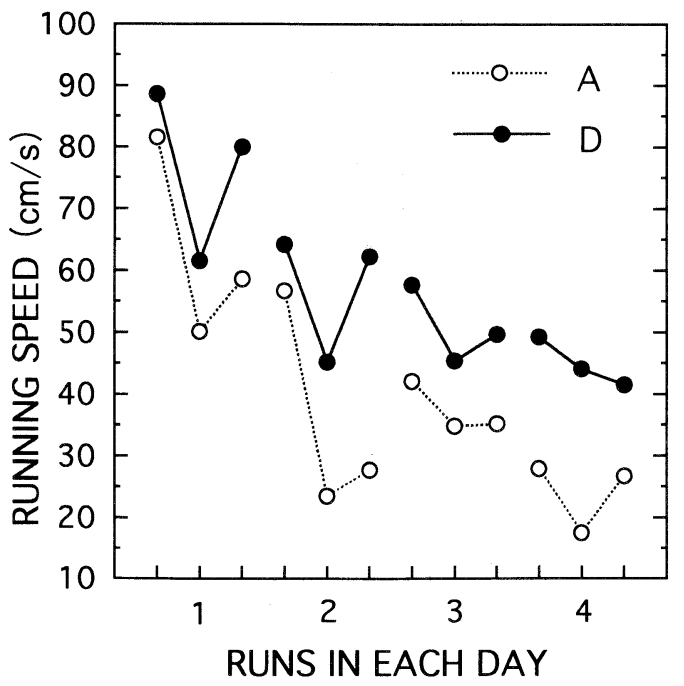

Figure 2. Running speeds for Groups A and D on each of three runs of the extinction series over the four days of extinction phase in Experiment 1.

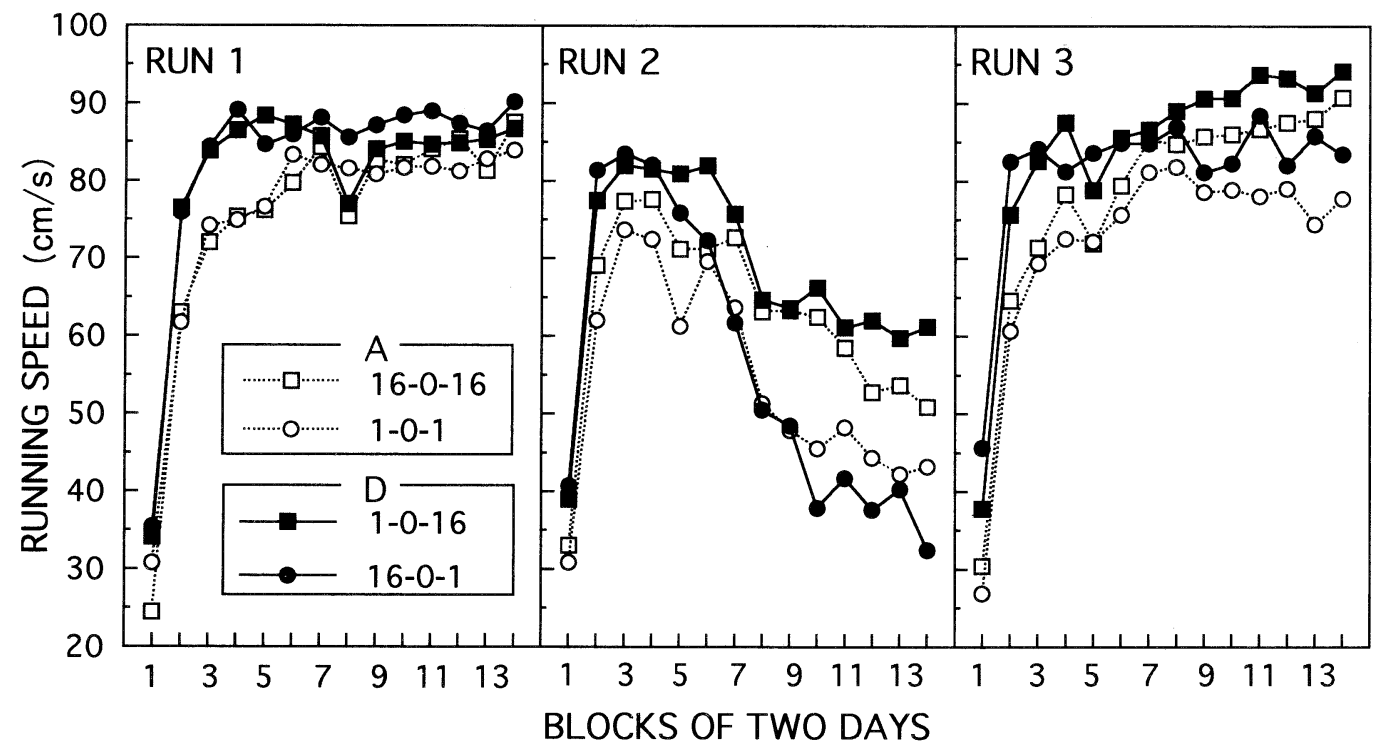

Figure 1. Running speeds for Groups A and D on each of their two different series on Run 1, Run 2, and Run 3 over fourteen blocks of two days during acquisition phase in Experiment 1. 
するものである.

消去については，A群よりも D 群の消去抵抗が有 意に高かった。両群に与えた系列は隣接連合によって 各シグナルが獲得すると期待される報酬信号強度は等 しい. 従って，両群間に認められた消去抵抗の差異を 隣接連合のみに基づいて説明することはできない。し 玑, 隣接連合に加えて遠隔連合も仮定寸ると, 消去 抵抗は，消去時に生じる $S^{0}$ と類似する $S^{1}$ が，小報酬 を信号する複合記憶 $\left(\mathrm{S}^{1+0} \rightarrow 1\right)$ から刺激般化を受け るA群よりも大報酬を信号する複合記憶 $\left(\mathrm{S}^{1+0} \rightarrow\right.$ 16）から刺激般化を受ける D 群において高くなるこ とが予測された，従って，消去抵抗についての結果 も，隣接連合に加えて遠隔連合を仮定する本研究の仮 説を支持するものだといえる.

\section{実 験 2}

水原（1993）の単一交替系列の習得と消去に関する 結果を本研究の仮説によって説明するためには，0ぺ レットに対する走行がこれに先行する報酬項目と後続 する報酬項目の両方に規定されること，および，遠隔 した項目間で，小報酬が小報酬を信号する場合より も，小報酬が大報酬を信号する場合に消去抵抗が高く なることが必要であった。実験 1 の習得および消去に 関する結果は，一貫してこの仮説を支持するものであ った。

そこで，実験 2 では，水原（1993）と同様の, 項目 数の多い系列の習得後の消去について, 法則弁別仮説 と遠隔連合仮説を比較する。 M16 群には 0-16-0-8-04-0-2-0-1 単調系列, $\mathrm{M} 1$ 群には 0-1-0-2-0-4-0-8-016 単調系列を与え, NM16 群には 0-16-0-2-0-4-0-80-1 非単調系列, NM1 群には 0-1-0-8-0-4-0-2-0-16 非単調系列を与える。これらの単一交替系列の習得後 の消去抵抗に関しては，法則弁別仮説と遠隔連合仮説 からは異なった予測が導かれる。まず，系列の法則構 造は NM16・NM1 非単調系列が M16・M1 単調系列 よりも複雑である。また，単調系列間および非単調系 列間では，報酬項目間の増減関係が逆転しているだけ で法則構造の複雑性は等しい. 従って, 法則弁別仮説 からは，消去抵抗は NM16=NM1>M16=M1 の順で 高くなると予測される。これに対し，消去時に生じる $\mathrm{S}^{0}$ と最も類似する $\mathrm{S}^{1}$ に刺激般化を及沽すと期待され る複合記憶 $\mathrm{S}^{1+0}$ は NM1 群では 8 ペレット, M1 群で は 2 ペレットを信号し，NM16群および M16群では 信号対象となる項目をもたない。また， $\mathrm{S}^{1}$ に次いで $\mathrm{S}^{0}$ と類似する $\mathrm{S}^{2}$ に刺激般化を及ぼすと期待される複 合記憶 $\mathrm{S}^{2+0}$ は NM1 群では 16 ペレット，M1 群と NM16 群では 4 ペレット，M16群では 1 ペレットを 信号する，従って，遠隔連合仮説からは，消去抵抗は NM1 >M1 > NM16>M16 の順で高くなると予測され

\section{方 法}

被験体 日本チャールズ・リバー社から購入した Sprague Dawley 系の雄ラット 32 匹を被験体として用 いた。被験体の内の 20 匹はスキナー箱でレバー押し を形成された経験があり，実験開始時に 130-160日 齢であった。他の 12 匹のラットは跳躍台で弁別訓練 を受けた経験があり，実験開始時に約 180 日齢であっ た。

\section{装置 実験 1 と同じ走路を用いた。}

手続き 実験 1 と同じ手続きの予備訓練を行った。 予備訓練終了の翌日から 12 日間の習得訓練を開始 した，過去経験について各群の匹数が等しくなるとい う制限の下で，ラットを無作為に4 群に振り分けた $(n=8)$. M16 群には 0-16-0-8-0-4-0-2-0-1 系列, M1 群には 0-1-0-2-0-4-0-8-0-16 系列, NM16 群に は 0-16-0-2-0-4-0-8-0-1 系列, NM1 群には 0-1-0-8 -0-4-0-2-0-16 系列をそれぞれ 1 日に 2 回ずつ提示し た. 走行間間隔は 15-20 秒間，系列間間隔は 25-30 分間であった。その他の手続きは実験 1 と同じであっ た.

習得訓練終了の翌日から消去訓練を 2 日間行った。 消去訓練では，すべての群に対して，10回の 0 ペレ ット走行からなる $0-0-0-0-0-0-0-0-0-0$ 系列を 1 日に 2 回与えた。その他の手続きは習得訓練と同じであっ た.

\section{結 果}

Figure 3 に習得訓練最終日における各群の平均走行 速度を示した. 群(4) ×項目 (10)の分散分析を施した ところ，群×項目の交互作用が有意であった（F[27, $252]=5.51, p<.01)$. その交互作用について項目の単 純主効果を吟味したところ, すべての群において有意 であった $(F \mathrm{~s}[9,252]=29.42: \mathrm{M} 16,39.48: \mathrm{NM} 16$, 24.87: M1, 30.92: NM1, $p \mathrm{~s}<.01)$. 各群における項目 の主効果について Newman-Keuls 検定を行った。そ の結果, 単調系列を与えられた M16 群と M1 群では 報酬項目間で走行速度の分化が認められ，M16群は 1 ペレットよりも 16,8 ，抢よび4ペレットに対して速 く, M1 群は 1 ペレットよりも $16,8,4$, および 2 ペ レットに対して速く走行した $(p s<.05)$. 非単調系列 を与えられた NM16 群と NM1 群ではいずれの報酬項 目間にも走行速度に有意な差は認められなかった。 0 ペレットに対する走行速度は, NM16 群では 2 ペレッ トよりも $16 \cdot 8 \cdot 4$ ペレットに後続する場合に遅く, M1 群では $1 \cdot 2$ ペレットよりも $8 \cdot 4$ ペレットに後続 する場合に遅く, NM1 群では 1 ・2ペレットよりも $16 \cdot 8 \cdot 4$ ペレットに後続する場合に遅く, 1 ペレット よりも 2 ペレットに後続する場合に遅かった（ $\mathrm{s}<$ .05).M16群では，0ペレットに対する走行速度は, 
16 ・2 ペレットよりも $8 \cdot 4$ ペレットに後続する場合 に遅かった $(p \mathrm{~s}<.05)$.

Figure 4 に消去訓練における各群の平均走行速度を

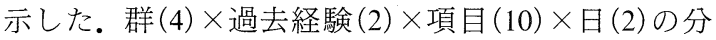
散分析を施したところ, 群の主効果 $(F[3,24]=$ $1.68)$ ，および群×日の交互作用 $(F[3,24]=2.24)$ は 有意ではなかった。補足的な分析として，訓練日ごと に群(4) ×過去経験 (2) ×項目 (10)の分散分析を施した ところ, 群の主効果は, 訓練 1 日目において有意であ り $(F[3,27]=4.88, p<.01)$, 訓練 2 日目では有意で はなかった $(F<1)$. 訓練 1 日目における群の主効果 についての Newman-Keuls 検定では, NM16 群, M1

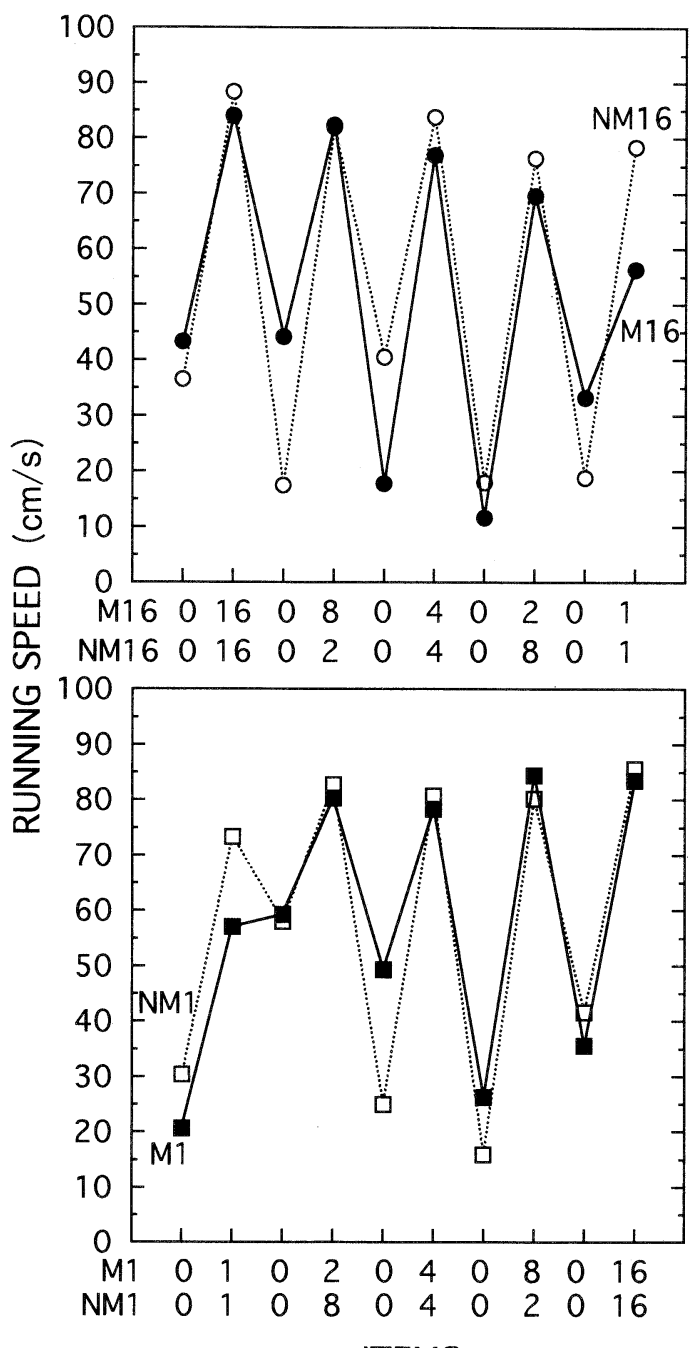

ITEMS

Figure 3. Running speeds for Groups M16 and NM16 (top panel) and for Groups M1 and NM1 (bottom panel) to items of their series on the last day of acquisition phase in Experiment 2.
群, およびNM1 群よりも M16群の走行が有意に遅 いことが示された $\left(p_{\mathrm{s}}<.05\right)$. NM16 群, M1 群，お よび NM1 群の走行速度の間に有意な差は認められな かった.なお，過去経験要因を含むすべての効果は有 意ではなかった $(p \mathrm{~s}>.05)$.

\section{考 察}

習得訓練に抢ける報酬項目間の走行速度の分化は， M16 群と M1 群では認められたが，NM16 群と NM1 群では認められなかった。この結果は, 報酬項目間に 0ペレットを挿入した系列においても, 報酬項目の報 酬量予期が非単調系列よりも単調系列において優れる ことを示した水原（1993）の結果を再現するものであ る.

0ペレットに対する走行については, すべての群に おいて 1 ・2ペレットという小報酬に後続する場合に 速いことが示された。この結果は，隣接連合の $\mathrm{S}^{0} \rightarrow$ $\mathrm{R}$ から $\mathrm{S}^{\mathrm{R}} \rightarrow 0$ に対して刺激般化が生じるために，0ぺ レットに対する走行は, 全般に, 先行する項目の報酬 量が小さいほど速くなる傾向があるとする本研究の仮 説と一致するように思われる。また，M16群では， 16 ペレットに後続する 0 ペレットに対しても速い走 行が見られた。この結果については，0-16-0-8-0-40-2-0-1 系列の 16 ペレットに後続する 0 ペレット走 行では, 隣接連合の $\mathrm{S}^{0} \rightarrow \mathrm{R}$ から $\mathrm{S}^{16} \rightarrow 0$ に対して刺激 般化が生じる傾向は低いが，8ペレットの遠隔予期が 生じるために，速い走行が生じると説明される。これ らの結果は, 報酬項目間に挿入された 0 ペレットに対 する走行が法則構造よりも先行および後続の項目の報 酬量に規定されることを示唆するものである。

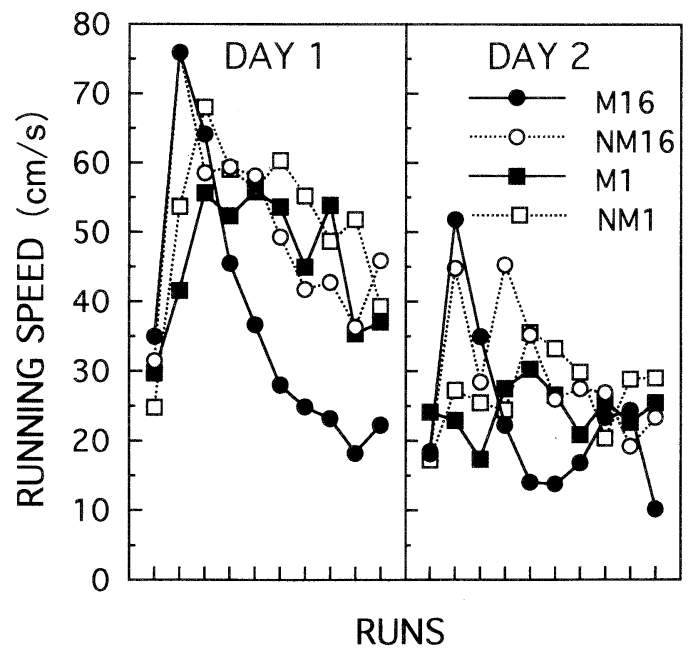

Figure 4. Running speeds for the four groups on each of the ten runs of extinction series over the two days of extinction phase in Experiment 2. 
また, 消去訓練の 1 日目では, 消去抵抗は M16 群 よりも NM1 群，M1 群およびNM16 群において高か つた。この結果のうち，M16群よりも NM1 群と NM16 群の消去抵抗が高くなることは法則弁別仮説と 遠隔連合仮説の両者が予測する。しかし，法則弁別仮 説は，法則構造の複雑性について等しい M1 群と M16群の間で消去抵抗に差が認められたという結果 を説明できない。これに対し，隣接連合に加えて遠隔 連合の形成を仮定する本研究の仮説からは, 消去時に 生起する $S^{0}$ と類似する $S^{1} や S^{2}$ が，M16群よりもM1 群において比較的に大報酬を信号する複合記憶から刺 激般化を受けるので，消去抵抗は M16 群よりも M1 群において高くなると予測された。従って, 消去抵抗 が M16 群よりも NM1 群, M1 群抢よびNM16群に おいて高かったという結果に関しては, 法則弁別仮説 よりも遠隔連合仮説を支持するものだといえる。

\section{全体的考察}

本研究は単一交替系列の習得における遠隔連合の形 成とその消去への関与を明らかにすることを目的とし た.

実験 1 では，R-N-R 系列において第 3 項目の報酬 量予期が示された。この結果は, 水原 (1993) や本研 究の実験 2 で使用されたような交替系列における報酬 項目間の走行速度の分化が遠隔連合の形成に媒介され うることを実証しており，強化系列の報酬項目間に 0 ペレットを挿入しただけでは項目間連合が形成される 可能性を排除できないことを示している。また，0ぺ レットに対する走行は，この項目に後続する報酬項目 が大報酬であるほど速くなるとともに，先行する報酬 項目が小報酬であるほど速くなることが示された。こ の結果は, 水原 (1993, 実験 2) の結果のうち, 単一 交替単調系列と単一交替非単調系列では 0 ペレットに 対する走行パタンが異なるという法則構造の学習から は説明困難な結果について, 項目間連合による説明の 根拠を提供するものである.

消去についても，実験 1 では，遠隔した項目間で小 報酬が小報酬を信号する場合よりも小報酬が大報酬を 信号する場合に消去抵抗が高くなることが示され，遠 隔連合が消去抵抗を規定する要因になりうることが示 された。また, 実験 2 では, 法則構造の複雑性につい て等しい M16 群と M1 群の消去抵抗に有意な差が認 められた。この結果は, 遠隔連合仮説の予測を支持す るものであり, 系列の法則構造の複雑性からは強化系 列習得後の消去抵抗を一義的には予測できないことを 実証している.

しかしながら，NM16 群，M1 群，およびNM1 群 の消去抵抗に有意な差が認められなかったという実験 2 の結果は, 遠隔連合仮説の予測も十分に満足するも のではなかった。このうち, NM16群と M1・NM1
群の消去抵抗に差が認められなかったという結果につ いては，系列の開始を信号する分節化手がかりが獲得 する報酬信号強度の差によって説明されるかもしれな い. Capaldi, Verry, Nawrocki, \& Miller (1984) は, 習得時に大報酬を信号した分節化手がかりの除去によ つて消去抵抗が低下することを報告している。この結 果は，分節化手がかりが獲得する報酬信号強度が消去 抵抗に影響することを実証するものである。

本研究の実験 2 における分節化手がかりは，実験室 への搬入と系列間間隔であると考えられる. 分節化手 がかりと第 2 項目との間に遠隔連合が形成されると仮 定すると，分節化手がかりは遠隔連合を通じて，M16 群と NM16群では 16 ペレットを信号し，M1 群と NM1 群では 1 ペレットを信号したと考えられる。こ こで，分節化手がかりと第 2 項目との間に遠隔連合が 形成された場合，第 1 項目の 0 ペレットに対する走行 は, 第 2 項目の遠隔予期が生じるために, 第 2 項目が 大報酬であるほど速くなると期待される。この仮説を 検証するため, 実験 2 の習得時の第 1 項目に対する走 行速度について，第 2 項目の報酬量（16，1 ペレッ ト) $\times$ 日（1-12 日目）の分散分析を施したところ， 第 2 項目の報酬量の主効果が有意であり，第 1 項目の 0 ペレットに対する走行は，第 2 項目が 1 ペレットの $\mathrm{M} 1 ・ \mathrm{NM} 1$ 群よりも16ペレットの M16 群・NM16 群 において速かった $(F[1,28]=4.23, p<.05)$.これは， 分節化手がかりが第 1 項目だけでなく第 2 項目をも信 号したことを示唆する結果であり，消去段階における 分節化手がかりの提示が M1・NM1 群よりも M16 ・ NM16 群の消去抵抗を選択的に高めた可能性を残すも のである．今後，分節化手がかりが獲得する報酬信号 強度について統制した条件下でこれらの群間の消去を 検討する必要があると思われる。

また，法則弁別仮説と遠隔連合仮説の両者が M1 群 よりも NM1 群の消去抵抗が高くなることを予測する が, これらの群間では消去抵抗に有意な差は認められ なかった。法則構造の複雑性や遠隔項目間の報酬信号 強度をさらに顕著にした条件下でこれらの群を比較す る必要がある。

本研究は，単一交替系列の習得に抢ける遠隔連合の 形成とその消去への関与の可能性について検討した。 しかしながら，このような試みは，ラットにおける法 則符号化過程の存在そのものを否定しょうとするもの ではない.ラットに扔ける強化系列の習得に関して は，系列の長さや法則構造の複雑性，または項目間の 時間間隔等に依存して, 法則符号化過程と項目連合過 程の両者が関与するという見解が提起され (Hulse, 1980)，これを支持する証拠も報告されてきている (Fountain, Schenk, \& Annau, 1985; 谷内, 1992). 本 研究の実験 1 では, 3 項目系列の習得後の消去抵抗 が，遠隔連合を含めた項目間連合の形成により説明さ 
れることが示された。しかし，さらに項目数の多い系 列を用いた実験 2 の消去については，遠隔連合仮説の 予測が十分には支持されなかった点で，法則符号化過 程の消去への関与の可能性を残している. 今後, 遠隔 連合を含めた項目連合過程と法則符号化過程の性質を 明らかにするとともに，各過程間の関係についても検 討する必要がある。

\section{引用文献}

Capaldi, E. J. 1967 A sequential hypothesis of instrumental learning. In K. W. Spence \& J. T. Spence (Eds.), The psychology of learning and motivation. Vol. 1. New York: Academic Press. Pp. 67-156.

Capaldi, E. J., \& Miller, D. J. 1988 The rat's simultaneous anticipation of remote events and current events can be sustained by event memories alone. Animal Learning \& Behavior, 16, 1-7.

Capaldi, E. J., \& Molina, P. 1979 Element discriminability as a determinant of serial-pattern learning. Animal Learning \& Behavior, 7, 318-322.

Capaldi, E. J., Nawrocki, T. M., \& Verry, D. R. 1983 The nature of anticipation: An inter- and intraevent process. Animal Learning \& Behavior, 11, 193-198.

Capaldi, E. J., \& Verry, D. R. 1981 Serial order anticipation learning in rats: Memory for multiple hedonic events and their order. Animal Learning \&
Behavior, 9, 441-453.

Capaldi, E. J., Verry, D. R., Nawrocki, T. M., \& Miller, D. J. 1984 Serial learning, interitem associations, phrasing cues, interference, overshadowing, chunking, memory, and extinction. Animal Learning \& Behavior, 12, 7-20

Fountain, S. B., Schenk, D. E., \& Annau, Z. 1985 Serial-pattern-learning processes dissociated by trimethyltin exposure in rats. Physiological Psychology, 13, 53-62.

Hulse, S. H. 1978 Cognitive structure and serial pattern learning by animals. In S. H. Hulse, H. Fowler \& W. K. Honig (Eds.), Cognitive processes in animal behavior. Hillsdale, NJ: Erlbaum. Pp. 311240.

Hulse, S. H. 1980 The case of the missing rule: Memory for reward vs. formal structure in serial pattern learning by rats. Animal Learning \& Behavior, 8, 689-690.

Hulse, S. H., \& Dorsky, N. P. 1977 Structural complexity as a determinant of serial pattern learning. Learning and Motivation, 8, 488-506.

水原幸夫 1993 ラットの強化系列学習の習得と消去 に及ぼす法則構造の効果 心理学研究, 64, 107-114.

谷内 通 1992 ラットの系列パタン学習における走 行間間隔と系列移行の効果 動物心理学研究, 42, 77-86.

1995. 12. 11 受稿, 1997. 3.15 受理 